\title{
Contribution of tropical cyclones to the sediment budget for coastal wetlands in Louisiana, USA
}

\author{
Andrew W. Tweel $\cdot$ R. Eugene Turner
}

Received: 7 June 2013/Accepted: 29 May 2014/Published online: 13 June 2014

(C) The Author(s) 2014. This article is published with open access at Springerlink.com

\begin{abstract}
The storm surge from a single hurricane can deposit tens of millions of tons of sediment on coastal wetlands within $100 \mathrm{~km}$ of landfall, but the distribution and cumulative amount from hurricanes at a centurial timescale is unknown. Here we use a model calibrated by three storms to estimate the average deposition on the deteriorating Louisiana coast from 1851 to 2008 . The total deposition on Louisiana coastal wetlands, exclusive of open water, averages 5.6 million tons of inorganic sediment per year, equivalent to $3.8 \%$ of the modern annual Mississippi River sediment load. Seventy nine percent of this sediment is deposited in a $20 \mathrm{~km}$ strip along the Gulf of Mexico $\left(7,400 \mathrm{~km}^{2}\right.$ wetlands) comprised primarily of salt marshes, and this distribution matches spatial and temporal patterns described in modern surficial deposits and sediment cores. We estimate that surge-induced deposition of sediment is attributable to at least $65 \%$ of the inorganic content of the top $24 \mathrm{~cm}$ of soils in abandoned delta lobes, and $80 \%$ in the chenier plain. While the most sedimentation from a given event results from the most intense storms, $78 \%$ of the long-term hurricane sedimentation results from moderate storms (930-990 $\mathrm{mb}$ ) that comprise $51 \%$ of tropical cyclone events.
\end{abstract}

A. W. Tweel $(\bowtie) \cdot$ R. E. Turner

Department of Oceanography and Coastal Sciences, School of the Coast and Environment, Louisiana State University, 1209 Energy, Coast, and Environment Building, Baton Rouge, LA 70803, USA

e-mail: atweel1@1su.edu
Furthermore, we estimate that the $47 \%$ of storms that make landfall with an internal barometric pressure above $990 \mathrm{mb}$ account for only $7 \%$ of the tropical cyclone sedimentation on wetlands.

Keywords Hurricane - Sedimentation - Salt marsh · Delta $\cdot$ Coastal wetlands

\section{Introduction}

Coastal wetlands provide storm protection for coastal communities by buffering storm surge, stabilizing shorelines, and reducing wave energy (Barbier et al. 2008; Costanza et al. 2008; Gedan et al. 2011; Shepard et al. 2011). The protection and restoration of coastal areas is projected to cost $\$ 50$ billion in Louisiana alone, and is largely centered on the delivery of sediment to the coastal landscape (CPRAL 2012). It is widely acknowledged that intense, but infrequent and often destructive storm surge events, such as those resulting from tropical cyclones and tsunamis, can result in the deposition of inorganic sediments which may get incorporated into the soil profile (Stone et al. 1997; Turner et al. 2006; Nanayama et al. 2007; Boldt et al. 2010; Tweel and Turner 2012a; Schuerch et al. 2012). These sediments can increase wetland elevation, slow wetland subsidence, and affect habitat quality (McKee and Cherry 2009). However, the frequency, magnitude, and spatial distribution of this 
sedimentation, as well as its influence on wetland soil development, are not well understood for Louisiana or other coastal systems.

The spatial pattern and structure of the coastal Louisiana wetland landscape is driven by the distribution of sediments both at and below the surface, and the organic accumulations from emergent vegetation which can form peat deposits (Kolb and van Lopik 1966; Kosters et al. 1987; Blum and Roberts 2009). The structure beneath the marsh landscape is characterized by delta lobe progradation and abandonment, which began when sea level rise decelerated 7-8 kya (Stanley and Warne 1994). Emergent wetland plants became established when inorganic sediments filled coastal waters sufficiently for plants to root. Delta lobes grew, river channels switched, and the downdrift chenier plain accumulated sediments that also began to support emergent vegetation (McBride et al. 2007). The result was a net gain in land $\left(19,000 \mathrm{~km}^{2}\right.$ by 1932 , Couvillion et al. 2011) comprised of uplands, chenier ridges, natural levees, barrier islands, and one of the most extensive wetland landscapes in the world. The surface soils at the active deltas are almost entirely comprised of inorganic sediments, and the variable sediment loads resulting from human activities upstream have been linked to variations in the extent of marsh vegetation at the mouth of the river (Tweel and Turner 2012b). The soil composition elsewhere, however, is a mixture of inorganics and organics, including peaty soils between abandoned channel networks (Kosters et al. 1987). Infrequent and spatially varied hurricane events can deposit $30 \times$ more sediments in a year (wetland platform only), than once annually flowed over previously unconfined river levees (wetlands and inshore waters), punctuating organic-rich soils with mineral-rich sediment layers (Turner et al. 2006, 2007). Hurricane-induced sedimentation is dispersed across the landscape at a coastwide scale, whereas sediments deposited after flowing overbank or through crevasses are more geographically limited (Kolb and van Lopik 1966). Consequently, the soils that develop in each of these environments are characterized by the proximity to, and frequency of, these sedimentation events.

About $80 \%$ of the total wetland sedimentation from a given hurricane striking Louisiana occurs within $20 \mathrm{~km}$ inland from the Gulf of Mexico, and $58 \%$ occurs within $50 \mathrm{~km}$ of the landfall location (Tweel and Turner 2012a). A 160-year history of
Louisiana hurricane landfalls suggests, however, that hurricane landfall location, timing, and intensity have varied widely across the coast (McAdie et al. 2009), and so the cumulative sedimentation from hurricanes may vary over space and time across the coastal Louisiana wetland landscape.

The long-term and coast-wide effect of these events on the distribution of inorganic sediment has been difficult to quantify because of the irregular and infrequent occurrence of the storms, and the logistical challenges of sampling across such a vast area in a timely manner after each storm. Here we investigate the long-term contribution of hurricane events to soil inorganic matter content in Louisiana coastal wetlands. We use a long-term and spatially explicit statistical model that includes historical records dating to 1851 and examine the results within the context of two independent, but complimentary, analyses of wetland soil characteristics for coastal Louisiana. One dataset describes the inorganic content of the top $24 \mathrm{~cm}$ of wetland soil across the coast (Tweel and Turner 2012b), and the other examines temporal fluctuations in mineral sediment deposition in deltaic plain salt marshes since 1910 (Turner et al. 2007).

\section{Methods}

Study area and model scope

The study area includes all wetlands (USFWS National Wetlands Inventory) within the coastal zone from the Louisiana/Mississippi border west to Galveston Bay (Fig. 1). The three hurricanes studied in this analysis crossed over a landscape of differing soils, vegetation, and geologic histories in both the chenier and deltaic plains. Hurricane Rita deposited sediment on intermediate, brackish, and fresh marshes, with a gradient of decreasing soil mineral content (top $24 \mathrm{~cm}$ ) ranging from $85 \%$ near the Gulf of Mexico to an average of $13 \%$ in the freshwater marshes farther inland (Tweel and Turner 2012b). Hurricanes Katrina and Gustav made landfall on remnant deltas of the Mississippi River. The most seaward $20 \mathrm{~km}$ of these areas is characterized by mineral-rich soils $(60-90 \%$ by weight) that support a vast expanse of Spartina alterniflora salt marshes (Tweel and Turner 2012b). Moving inland from the Gulf, marsh types transition to brackish, intermediate, and then freshwater wetland, 


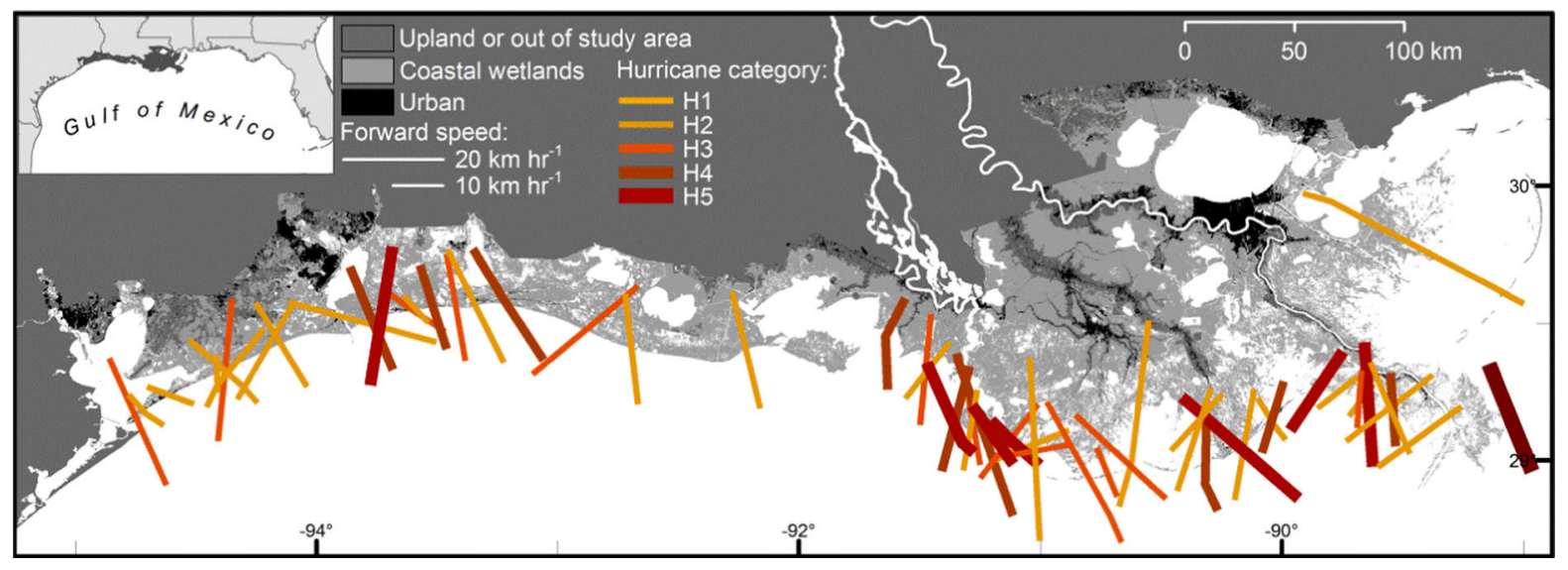

Fig. 1 Hurricane landfalls in Louisiana and Texas west to Galveston Bay from 1851 to 2008. Bar lengths show hurricane forward speed, and line thickness corresponds to storm strength.
The inset shows the general location of study area (black). Hurricane strength $(\mathrm{H})$ is defined by the Saffir-Simpson hurricane intensity scale, where $\mathrm{H} 5$ is the strongest storm and soil types become progressively more organic along this same gradient. The uppermost marshes of Barataria Bay, for instance, are characterized by freshwater marshes with peaty soils (7\% mineral).

Remnant distributary ridges, natural levees along the Mississippi River, and cheniers contain more mineral soils, but are generally characterized by upland habitats which were not of interest to this study. Non-marsh areas were excluded from this analysis along with developed areas that may have historically been wetland. Although we were primarily interested in wetland sedimentation within the deltaic and chenier plains of Louisiana, we included coastal wetlands west to Galveston Bay because tropical cyclone effects can extend hundreds of kilometers from landfall (Cahoon et al. 1995; Turner et al. 2006). Hurricane Ike, for instance, made landfall at the western edge of our study area, but produced significant sedimentation in the Louisiana chenier plain (Williams 2012).

Historical tropical cyclone data for Louisiana

We used NOAA's HURDAT database to isolate tropical cyclones (hurricanes, tropical storms, and tropical depressions) entering the study area between 1851 and 2008 (http://www.aoml.noaa.gov/hrd/ hurdat/Data_Storm.html). This database contains the geographic location, wind speed, barometric pressure, and Saffir-Simpson category for all known tropical cyclone events in the Atlantic Basin at 6-h intervals.
We assumed that the event characteristics preceding landfall were most representative of those at landfall. Additional events may have resulted in sedimentation within the study area, such as tropical cyclones passing near coastal Louisiana but not making landfall.

\section{Model parameterization}

We investigated the quantity and distribution of wetland sedimentation following three recent sedimentation events: Hurricanes Katrina (2005), Rita (2005), and Gustav (2008). With regard to historical landfalls, the characteristics of these storms were representative of the database, with their parameters falling within range of common landfall speeds and approach angles (Fig. 2). These hurricanes resulted in the deposition of $68 \pm 9,48 \pm 8$ and $21 \pm 4 \times 10^{6} \mathrm{t}$, respectively, of inorganic sediment on the marsh surface (Tweel and Turner 2012a). This deposition, whether on only wetlands or extrapolated to include inshore waters, was inversely proportional to storm intensity as measured by barometric pressure at landfall (Fig. 3a), and proportional to wind speed at landfall. We used this relationship as the basis for modeling the total wetland sedimentation from historical events as a function of pressure (Table 1). When pressure data were not available, especially before 1960, we estimated pressure based on its relationship to wind speed ( $p<0.0001$, Fig. 4). Prediction error for this relationship at the mean wind speed was $1.2 \%$ (95\% confidence). We used a 


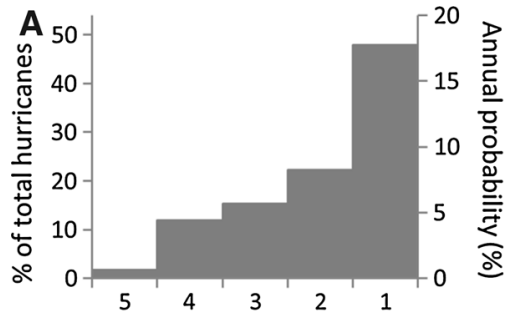

Hurricane category at landfall
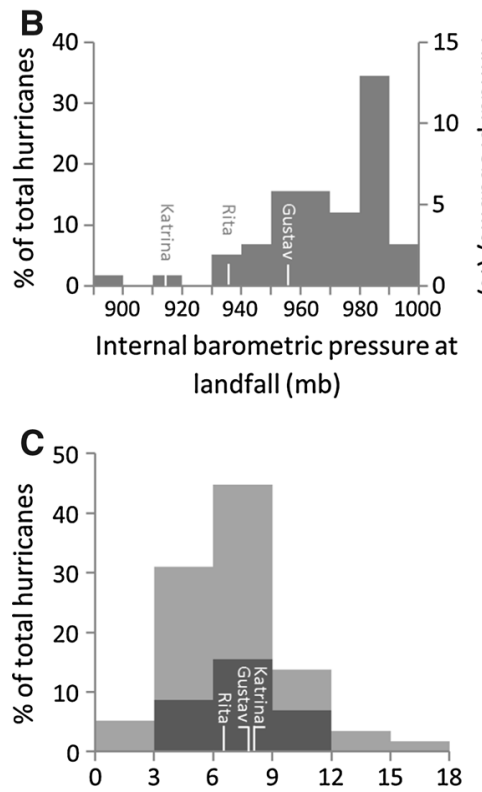

Forward speed at landfall $\left(\mathrm{km} \mathrm{hr}^{-1}\right)$

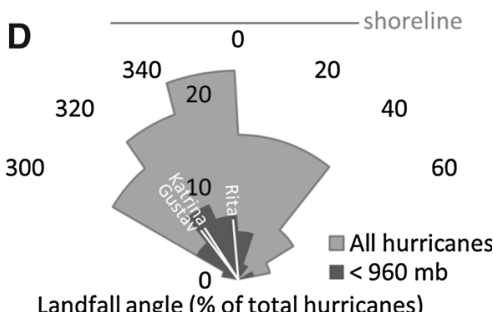

Fig. 2 Probability distributions for hurricane landfalls in the study area, based on data from 1851 to 2008. a Saffir-Simpson hurricane intensity scale, b internal pressure $(\mathrm{mb})$ at landfall, c forward speed at landfall $\left(\mathrm{km} \mathrm{h}^{-1}\right)$ for all hurricanes (light gray) and hurricanes with landfall pressure below $960 \mathrm{mb}$, and, d direction of hurricane travel at landfall relative to $2 \mathrm{~m}$ isobath for all hurricanes (light gray) and hurricanes with landfall pressure below $960 \mathrm{mb}$

square-root transformation of pressure to meet parametric assumptions, and this relationship was significant with and without transformation. We also tested the relationship of deposition to other variables such as
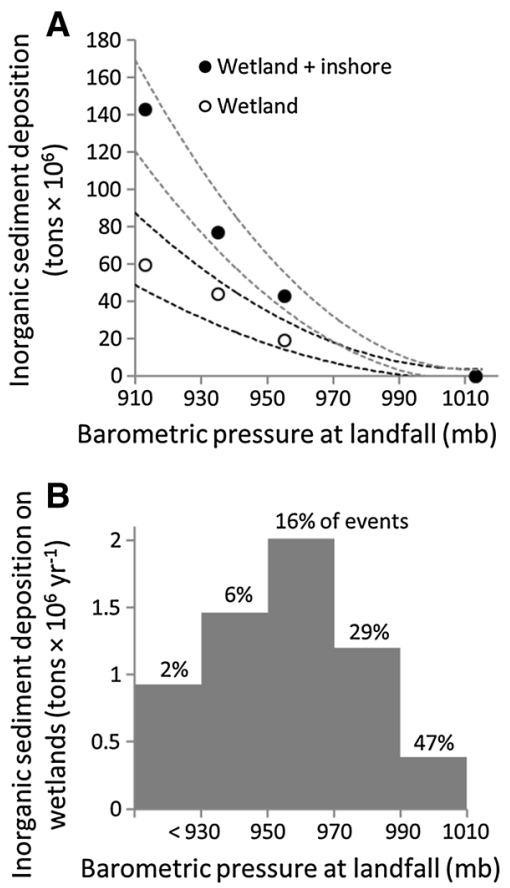

Fig. 3 a Relationship between pressure at landfall and total wetland deposition in the study area $( \pm 95 \% \mathrm{CI}$, open circles $)$ and wetland plus extrapolated inshore subaqueous (at mean sea level) deposition (solid circles), and $\mathbf{b}$ distribution of sediment deposition by landfall barometric pressure for all Louisiana HURDAT events

the extent of tropical storm force winds at landfall, but these did not explain as much variance as internal barometric pressure.

We previously observed that sediment deposition within each storm event decayed with distance from storm track and distance from shoreline (Tweel and Turner 2012a), and used this as a starting point to model sediment deposition within a given event. Because of differing land-to-water ratios within the study areas that would have introduced more variability, we used combined estimates for wetland and inshore subaqueous sedimentation for the whole area, and then subtracted out the percent of water pixel-bypixel. The final estimates of total deposition we present are, therefore, for marsh-only deposition.

We used a grid size of $10 \mathrm{~km}$ to meet our objective of producing a landscape-scale statistical model, and as a reasonable scale to match the precision of our sedimentation estimates and the uncertainties of the HURDAT storm tracks (McAdie et al. 2009). Additionally, Louisiana has experienced significant 
Table 1 Statistics and regression parameters used to estimate the total inorganic sediment deposition per event, and the spatial distribution of sedimentation within events

\begin{tabular}{|c|c|c|c|c|c|c|}
\hline Model & Variable & Coefficient & $F$ & $p$ & Adj. $R^{2}$ & $n$ \\
\hline \multicolumn{7}{|c|}{ Total deposition (tons $\times 10^{6}$ ) } \\
\hline \multirow[t]{3}{*}{ Wetland + inshore } & $=\left(b_{0}+b_{1} P\right)^{2}$ & & 718.37 & 0.0014 & 0.99 & 4 \\
\hline & Intercept & $b_{0}: 119.15696$ & & 0.0012 & & \\
\hline & Pressure $^{\mathrm{a}}(P)$ & $b_{1}:-0.11775$ & & 0.0014 & & \\
\hline \multirow[t]{3}{*}{ Wetland only } & $=\left(b_{0}+b_{1} P\right)^{2}$ & & 246.60 & 0.0040 & 0.99 & 4 \\
\hline & Intercept & $b_{0}: 80.42468$ & & 0.0036 & & \\
\hline & Pressure $^{\mathrm{a}}(P)$ & $b_{1}:-0.07939$ & & 0.0040 & & \\
\hline \multicolumn{7}{|c|}{ Spatial distribution ( $\%$ of total per $10 \mathrm{~km}$ pixel) } \\
\hline \multirow[t]{7}{*}{ W Model ${ }^{\mathrm{b}}$} & $=\left(b_{1} T^{2}+b_{2} T+b_{3} C+b_{4} C \times T+b_{5} T \times P+b_{0}\right)^{2}$ & & 77.27 & $<0.0001$ & 0.73 & 143 \\
\hline & $\operatorname{Track}\left(T^{2}\right)$ & $b_{1}:-0.00201$ & & $<0.0001$ & & \\
\hline & Track $(T)$ & $b_{2}: 0.14523$ & & $<0.0001$ & & \\
\hline & Coast (C) & $b_{3}:-0.04347$ & & $<0.0001$ & & \\
\hline & Coast $\times$ track $(C \times T)$ & $b_{4}: 0.00301$ & & $<0.0001$ & & \\
\hline & Track $\times$ pressure $^{\mathrm{a}}(T \times P)$ & $b_{5}:-0.00014$ & & $<0.0001$ & & \\
\hline & Intercept & $b_{0}: 0.21407$ & & $<0.0001$ & & \\
\hline \multirow[t]{5}{*}{ E Model $^{\mathrm{c}}$} & $=\left(b_{1} T^{2}+b_{2} T+b_{3} C+b_{0}\right)^{2}$ & & 109.74 & $<0.0001$ & 0.75 & 110 \\
\hline & Track $\left(T^{2}\right)$ & $b_{1}: 0.00001$ & & $<0.0001$ & & \\
\hline & Track $(T)$ & $b_{2}:-0.00181$ & & $<0.0001$ & & \\
\hline & Coast $(C)$ & $b_{3}:-0.00112$ & & $<0.0001$ & & \\
\hline & Intercept & $b_{0}: 0.16253$ & & $<0.0001$ & & \\
\hline
\end{tabular}

Distances are measured in $\mathrm{km}$ and pressure is measured in $\mathrm{mb}$, see text for explanation of equations

${ }^{a}$ Pressure at landfall in $\mathrm{mb}$

b Distances in $\mathrm{km}$. Inputs of all distances are square-root transformed

c Distances in $\mathrm{km}$. Inputs of distance from track are square-root transformed

wetland losses since the 1930s, and so this larger scale helps buffer some of the bias introduced by shorelines that may have changed throughout the study period. The deposition data modeled here were the estimates of total deposition derived using inverse distance weighting reported previously (Tweel and Turner 2012a). The total sample size was 263 pixels, with an average percent wetland of $51.3 \pm 1.3 \%(\mu \pm \mathrm{SE})$. Because the spatial distribution of sedimentation resulting from Hurricane Katrina was quite different from that of Rita and Gustav (Tweel and Turner 2012a), we fit two separate spatial distribution regression models: the first was based on data from Hurricanes Rita and Gustav which made landfall west of the Mississippi River and had their greatest impact east of the storm track (W Model), and the second was based on data from Hurricane Katrina, which passed over Breton Sound east of the Mississippi River and had the bulk of its Louisiana effect to the west of the storm track (E Model, Table 1). Modeled events were classified according to whether or not they passed over the Breton Sound basin at any point, which included 17 of the 58 modeled hurricane events. This distinction follows previously reported differences in sedimentation patterns, storm surge heights, and modeled storm surges between storms passing over the eastfacing Breton Sound Basin and south-facing coast west of the Mississippi River (USACE 1972; Dietrich et al. 2010). We excluded nine pixels in the Mississippi River birdfoot delta and Biloxi Marsh where no sediment sampling occurred. Because of the long time period being studied, we excluded one observation of anomalously high sedimentation from the same location where altered storm surge dynamics have been attributed to anthropogenic landscape modifications in the upper Breton Sound Basin that were not in place for the majority of the study period (Mashriqui et al. 2006; Ebersole et al. 2010). 


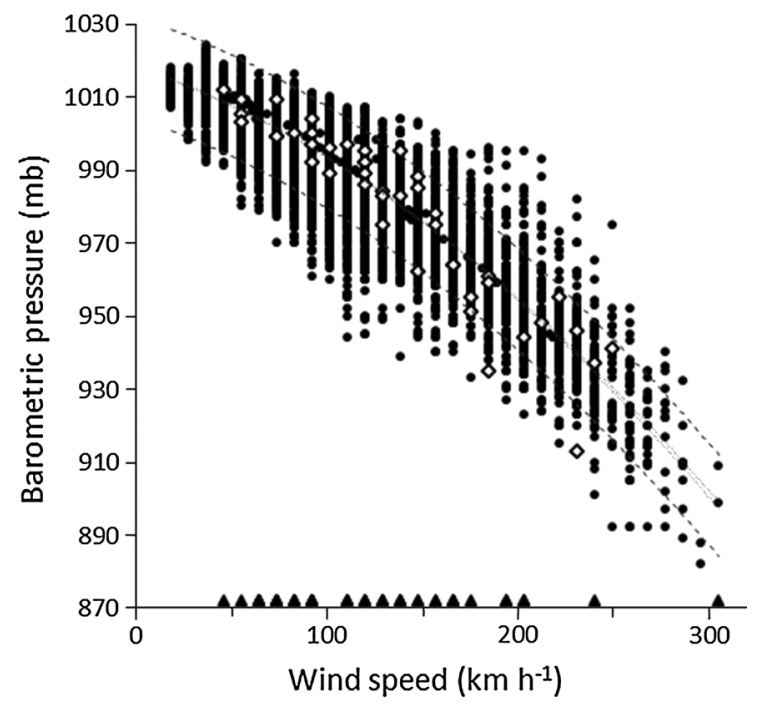

Fig. 4 Relationship between wind speed and internal barometric pressure at landfall for Louisiana (white diamonds) and all other Atlantic observations (black dots) from 1851 to 2008. The outer bands mark the $95 \%$ prediction interval and the inner bands mark the $95 \%$ confidence interval. Wind speed observations where pressure was estimated are shown at bottom (black triangles)

We used a backward-selection multiple polynomial regression to fit the most appropriate models (PROC REG, SAS Institute, Cary, NC), and selected variables based on distance decay relationships observed earlier (Tweel and Turner 2012a). The independent variables were distances to coastline and storm track in $\mathrm{km}$, and, in the case of the $\mathrm{W}$ model, barometric pressure at landfall. We used percent of total, as opposed to absolute deposition in grams per square centimeter, to allow for scaling of the output according to storm intensity. For this analysis, we defined the coastline as following the outer shoreline of the barrier islands, and the landward extent of open water for the large $(20 \mathrm{~km})$ coastal bays (e.g., Barataria, Terrebonne, Breton Sound). We generalized the complex shorelines of the large coastal bays using the Simplify Polygon function (ArcInfo 10.0, ESRI, Redlands, CA, USA), and then extended this boundary seaward $5 \mathrm{~km}$ to account for smaller features that may have been smoothed over. This served as the reference line from which the distance measurements were taken. If this line was defined differently, the model results would remain unchanged, just measured from a different reference point.

We started modeling with third-order polynomial functions, and also tested linear interactions between the independent variables. These additional terms allowed the depositional surface to vary throughout the study area. The decay relationship away from the storm, for example, might be different than nearer the storm. Variables that were not significant were removed, and the regressions were reanalyzed. We tested for normality of residuals and used partial residuals and the PRESS statistic to ensure that the dependent variable was adequately modeled and that the most appropriate models were selected. We restricted the depositional area to within $150 \mathrm{~km}$ from the storm track in both models, and also to the area east of the track for the $\mathrm{W}$ model. The latter decision was based on observations of the distribution of mineral sediment on the marsh surface following hurricane events in 2005 and 2008, which revealed no instances of sedimentation $(>0.5 \mathrm{~cm})$ west of the track for Rita and Gustav-type events (Tweel and Turner 2012a). Our final model results are presented in grams inorganic matter per square centimeter of wetland, rather than total sedimentation per pixel which would not account for potential differences between sedimentation on the marsh platform and subaqueous sedimentation.

Model application

We estimated the total inorganic wetland deposition and spatial distribution for each event between 1851 and 2008 that has been categorized as Category 1 or higher on the Saffir-Simpson scale for a $10 \mathrm{~km}$ grid of coastal Louisiana. We then combined these estimates to determine the cumulative deposition in coastal wetlands, and divided by the number of years in the study period to determine an annual average rate of inorganic sediment deposition resulting from hurricane events. We then compared these results to both planar and stratigraphic distributions of mineral sediment for coastal Louisiana wetland soils (Turner et al. 2007; Tweel and Turner 2012b).

\section{Model limitations}

This model is a landscape-scale or event-scale model of coastal marsh sedimentation resulting from hurricanes in Louisiana. We did not include tropical storms and tropical depressions in the spatial model, although we estimated the total deposition from these smaller events based on their pressure. There are no landscapescale tropical storm or tropical depression data 
currently available to describe the spatial distribution sediment deposited on the marsh surface following these events.

Sedimentation from tropical cyclone events may also vary on a more local scale $\left(10^{3} \mathrm{~m}\right)$ due to local bathymetry or channel morphology (Miner et al. 2009; Otvos 2011) or even smaller scales $\left(\leq 10^{\circ} \mathrm{m}\right)$ such as vegetative cover (Rejmanek et al. 1988). The model is calibrated, therefore, for the mean wetland sedimentation in a given pixel, and may be locally higher or lower within that pixel. This result is consistent with our objective of identifying long-term patterns in sediment distribution on this coast, whereby smaller variations, although locally significant, would be of less consequence to the long-term and large-scale trends. Because the model is based on geographic characteristics of sedimentation events in Louisiana's gently-sloping coastal plain, we expect that the model parameters would vary for other geographic locations. We also assume that wind speed and internal barometric pressure at landfall are the dominant factors determining sedimentation, as identified by the three study events, although additional factors such as approach angle, storm size, and forward speed may also be factors (Irish et al. 2011). The storm events studied here are representative of the most common types in terms of forward speed and approach angle, while still providing a gradient of storm intensities to examine (Fig. 2). Future research on tropical cyclone sedimentation events should identify if and how these additional factors may also affect the distribution and magnitude of wetland sedimentation. We did not study or model subaqueous sedimentation or erosion, which can be significant (Miner et al. 2009; Freeman and Roberts 2012), but are much more difficult to study at the landscape scale.

\section{Results}

Between 1851 and 2008 coastal Louisiana and the adjacent Texas coast (Galveston Bay to the Louisiana border) were traversed by 58 hurricanes ranked as Category 1 or greater on the Saffir-Simpson scale (Fig. 1), and 55 tropical storms or tropical depressions. The annual probability of hurricane landfall decreased with increasing storm intensities (Fig. 2). The cumulative effect of all modeled hurricanes would be equivalent to an annual inorganic sediment deposition of $5.6 \times 10^{6} \mathrm{t}$ in Louisiana coastal wetlands. The amount for the Bolivar Peninsula in Texas $\left(4 \times 10^{5} \mathrm{t} \mathrm{year}^{-1}\right)$ is likely underestimated because it does not account for storms tracking south of Galveston Bay.

The deltaic plain receives $64 \%$ of the total hurricane deposition on Louisiana coastal wetlands, and those in the chenier plain receive $26 \%$. We estimate that $65 \%$ of the total Louisiana deposition from all tropical cyclone events (hurricanes plus tropical storms) results from events with landfall barometric pressure below $960 \mathrm{mb}$ (approximately Category 3 or greater; $16 \%$ of all HURDAT events), with $92 \%$ resulting from events ranked as Category 1 or greater (51\% of events, Fig. 3b). Additionally, $79 \%$ of the total estimated long-term hurricane sedimentation (i.e., not including tropical storms) occurs within the first $20 \mathrm{~km}$ inland from the coastline $\left(7,400 \mathrm{~km}^{2}\right.$ wetlands) and $50 \%$ occurs in the first $10 \mathrm{~km}$ inland, which is similar to the observations from discrete events studied previously (Tweel and Turner 2012a).

The average deposition of inorganic sediment resulting from hurricane events is $0.047 \mathrm{~g} \mathrm{~cm}^{-2}$ year $^{-1}$ for all Louisiana coastal wetlands, but the spatial distribution is highly variable $(\sigma=0.031)$. The greatest sedimentation appears to occur in the marshes flanking Terrebonne and Barataria Bays, where up to $0.16 \mathrm{~g} \mathrm{~cm}^{-2}$ year $^{-1}$ of inorganic sediment is deposited. By comparison, the model indicates that inorganic sediment deposition in the upper reaches of Barataria Basin from hurricanes is less than $0.01 \mathrm{~g} \mathrm{~cm}^{-2}$ year $^{-1}$ (Fig. 5). Mean deposition rates decreased along a marine to freshwater gradient of marsh types as follows: salt $\left(0.082 \mathrm{~g} \mathrm{~cm}^{-2}\right.$ year $\left.^{-1}\right)$, brackish $\left(0.051 \mathrm{~g} \mathrm{~cm}^{-2}\right.$ year $\left.{ }^{-1}\right)$, intermediate $\left(0.036 \mathrm{~g} \mathrm{~cm}^{-2}\right.$ year $\left.^{-1}\right)$, freshwater $\left(0.032 \mathrm{~g} \mathrm{~cm}^{-2}\right.$ year $\left.^{-1}\right)$. If considered separately, the rate for freshwater marshes at the mouth of the Mississippi River is $0.057 \mathrm{~g} \mathrm{~cm}^{-2}$ year ${ }^{-1}$ and for all other freshwater marshes the mean annual rate is $0.028 \mathrm{~g} \mathrm{~cm}^{-2}$ year $^{-1}$.

The spatial distribution of hurricane landfalls varied throughout the study area. The greatest landfall density was in the $60 \mathrm{~km}$ stretch of coastline between Point Chevreuil and Sister (Caillou) Lake. This area was traversed by 15 Category 1 or greater events during the study period, while the nearby $60 \mathrm{~km}$ stretch from Marsh Island to Tigre Point received only 1 landfall. These differences are apparent in the spatial distribution of long-term hurricane sedimentation rates (Fig. 5). 


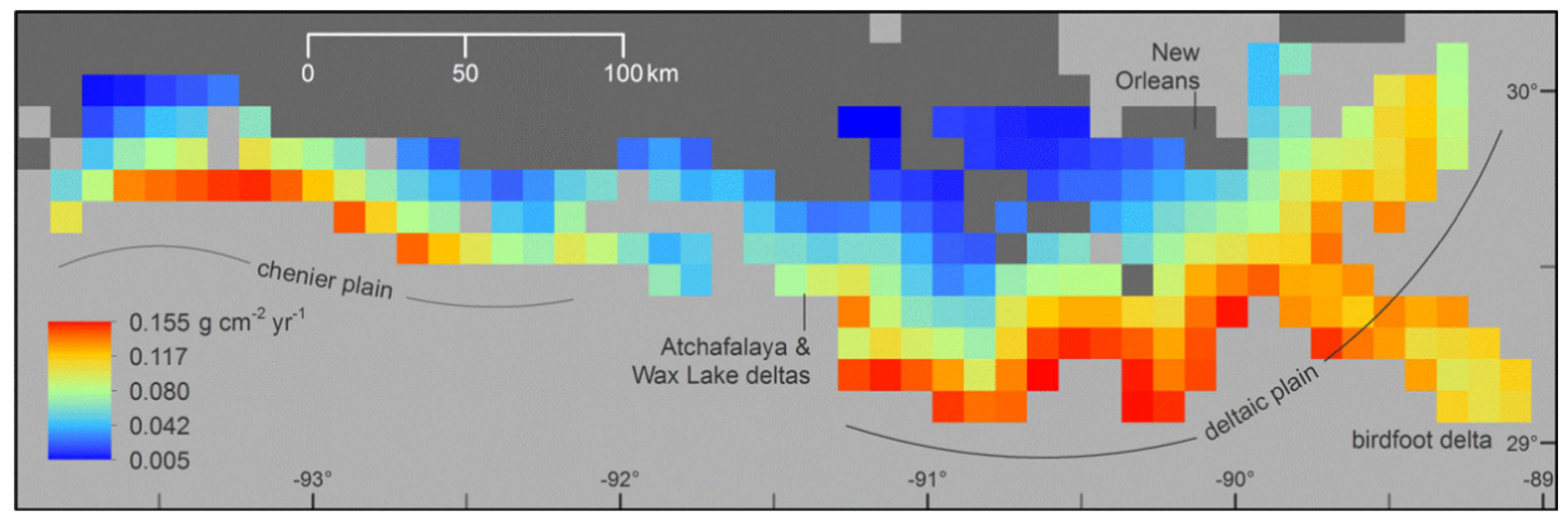

Fig. 5 Spatial distribution of mean annual hurricane sedimentation for coastal Louisiana wetlands. The data are based on estimated deposition from Category One and greater events from 1851 to 2008

Model performance

All parameters for the total deposition model are statistically significant (Table $1, p<0.01$ ), as are all parameters for the spatial distribution model $(p<0.0001)$. Although the full statistical model compares well to the broad range of sedimentation observed in three recent events $\left(R^{2}=0.72\right.$, $\left.F_{(1,777)}=1952, p<0.001\right)$, it tends to under-predict at the largest values and over-predict at the smallest values. The largest 9 observations have high leverage on the validation line, and the slope increases from 0.70 to 0.82 for the remaining $98.8 \%$ of the data $\left(R^{2}=0.69, F_{(1,768)}=1,731, p<0.001\right.$; Fig. 6). This prediction plot incorporates the variability introduced by estimating the total deposition as well as the spatial distribution. The deposition values below $0.01 \mathrm{~g} \mathrm{~cm}^{-2}$ are over-predicted, but there are few $(<10)$ observations this small. We estimate that the bottom $1.3 \%$ of data is over-predicted by nearly $50 \%$, and that the top $1.2 \%\left(>6.9 \mathrm{~g} \mathrm{~cm}^{-2}\right)$ is under-predicted by $43 \%$. The $95 \%$ prediction interval contains $93 \%$ of the data.

\section{Discussion}

The annual deposition of sediment on the marsh surface from hurricanes is estimated to be $5.6 \times 10^{6}$ $\mathrm{t}$ of inorganic sediment for Louisiana coastal wetlands, which, for comparison, equates to $3.8 \%$ of the modern annual Mississippi River load (Meade and Moody 2010) and 3.2 \% of the estimated pre-disturbance load (Tweel and Turner 2012b). The spatial

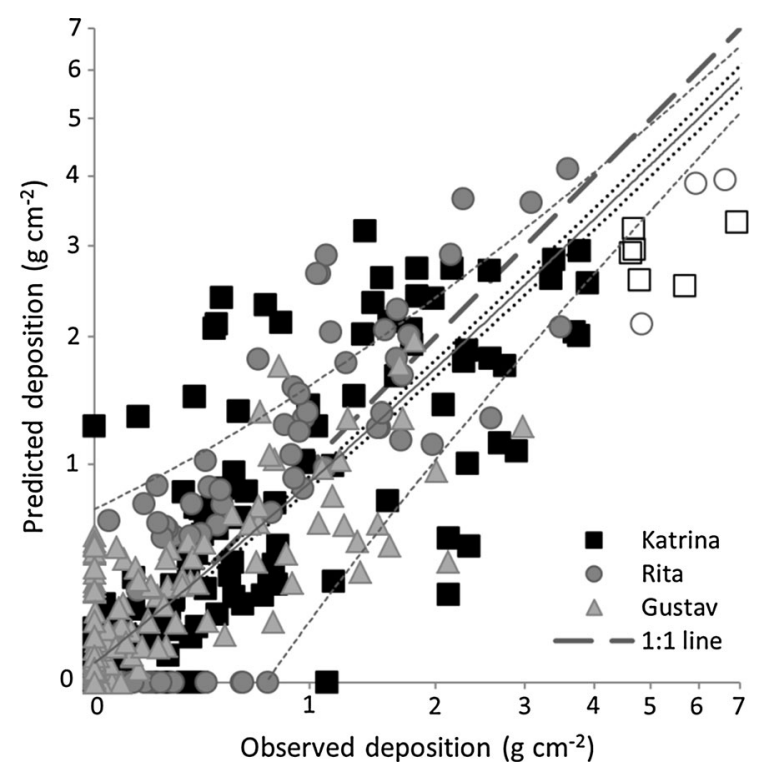

Fig. 6 Prediction plot showing model performance at study scale for Hurricanes Katrina, Rita, and Gustav. The outer bands mark the $95 \%$ prediction interval, the inner bands mark the $95 \%$ confidence interval, and the open shapes indicate the most under-predicted values. The axes are scaled logarithmically to increase resolution at lower values

distribution, however, varies along the coast with landfall location and with distance inland as storm surge intensity, and thus sediment transport capacity, is reduced. We estimate that, by dividing the average estimated hurricane sedimentation rates for the deltaic and chenier plains by the total inorganic sedimentation rates for the same areas (Table 16 in Piazza et al. 2011), $65 \%$ of the inorganic sediment in wetland soils 
of the deltaic plain, and $80 \%$ for the chenier plain, could directly result from hurricanes making landfall in the study area. These are conservative estimates, because additional sedimentation may result from tropical storms and from hurricanes passing near the study area but not making landfall.

The magnitude and chronology of sedimentation events developed from this analysis compares well to the inorganic content of 51 deltaic plain salt marsh cores representing the period from 1910 to 1993 as identified using ${ }^{210} \mathrm{~Pb}$ and ${ }^{137} \mathrm{Cs}$ dating techniques (Fig. 7; $\quad R^{2}=0.62, \quad F_{(1,82)}=137.73, \quad p<0.001$; Turner et al. 2007). While discrete event laminae are typically not recognizable in centuries-old peat, periods of high hurricane activity correspond to peaks in mineral content relative to soils formed in the absence of hurricanes. The largest peaks between 1910 and 1990 occur around 1970 for both datasets. This span from 1964 to 1974 marks the period of greatest historical hurricane frequency for Louisiana, during which it was struck by four hurricanes ranking Category 3 or greater, as well as one Category 2 event. The core data show a smoothed peak in mineral sediment content, rather than discrete events, indicating that as sediments are consolidated, some of this sediment may be redistributed vertically. Peaks in hurricane activity and intensity also correspond to peaks in soil mineral content around 1915 (2 unnamed Category 3 events) and 1992 (Hurricane Andrew). The difference in relative magnitudes between the 1970 peak and 1992 for the modeling and core study is expected because the sediments from Hurricane Andrew were relatively recently deposited at the time of collection, while the older sediments had become diluted by autogenic sedimentation over three decades (Turner et al. 2007).

Our model of long-term hurricane sedimentation is consistent with broad-scale trends in the spatial distribution of wetland soil types along the Louisiana coast. Wetland soils where inorganic content in the top $24 \mathrm{~cm}$ comprises about $60 \%$ of soil mass are found in two main areas along this coast: active deltas and salt marshes. There are two distinct clusters that do not fit the general trend: the Mississippi River birdfoot delta and the Atchafalaya/Wax Lake deltas, through which almost all of the Mississippi River discharge passes (Fig. 8; $R^{2}=0.51, F_{(1,153)}=159.95, p<0.0001$ ). The dominant inorganic sediment source for these wetland soils is from the deposition of suspended sediments directly from the river rather than the resuspension of sediments by storm-associated waves (Tweel and Turner 2012b). The asymptotic appearance of the overall curve (maximum is near $80 \%$ inorganic content for deltaic plain soils, regardless of rate of input) may result from a minimum threshold of organic content due to the presence of salt marsh vegetation.

The marine-dominated sediment budget for inactive delta portions of the Louisiana coast exhibits similarities to some other coastal wetlands, such as the Ganges-Brahmaputra delta in Bangladesh. Using grain size-normalized ${ }^{137} \mathrm{Cs}$ inventories, it was reported that between 7 and $13 \%$ of the annual Ganges-Brahmaputra sediment load is delivered to the Sunderbans delta plain during cyclonic and monsoonal events (Allison and Kepple 2001), which is within range of the estimate for this study. The Sunderbans is also characterized by a decreasing inland trend of inorganic sediment accretion comparable to the trend we observe for the Louisiana deltaic plain. Similarly, accretion rates in a German salt marsh are driven primarily by periods of high storm activity and storm surge events (Schuerch et al. 2012). Consistent sediment input from historic and prehistoric storm events has also been observed in New England (Boldt et al. 2010) and mid-Atlantic salt marshes (Stumpf 1983).

This reworking of deltaic sediment follows the widely used delta cycle model of overwash processes that regulate barrier island development and decay (Penland et al. 1988), albeit at a larger scale-up to hundreds of kilometers from source to sink. In the absence of anthropogenic landscape modification, marine-dominated coastal wetlands can persist for thousands of years, with vertical accretion driven largely by organic accretionary processes (Turner et al. 2002; McKee et al. 2007), but supplemented by tropical cyclones and more local sedimentation events. An example of this persistence of wetlands is the Biloxi Marsh, in the abandoned St. Bernard Delta of the Mississippi River (4,000-2,000 BP), which has one of the lowest land loss rates along the Louisiana coast (Couvillion et al. 2011). Areas of high historic (post 1932) land loss do not appear to be coincidental with the observed patterns in hurricane sedimentation. These areas of high land loss have been subjected to a variety of natural and anthropogenic stressors including altered sheet flow hydrology via canal dredging, 


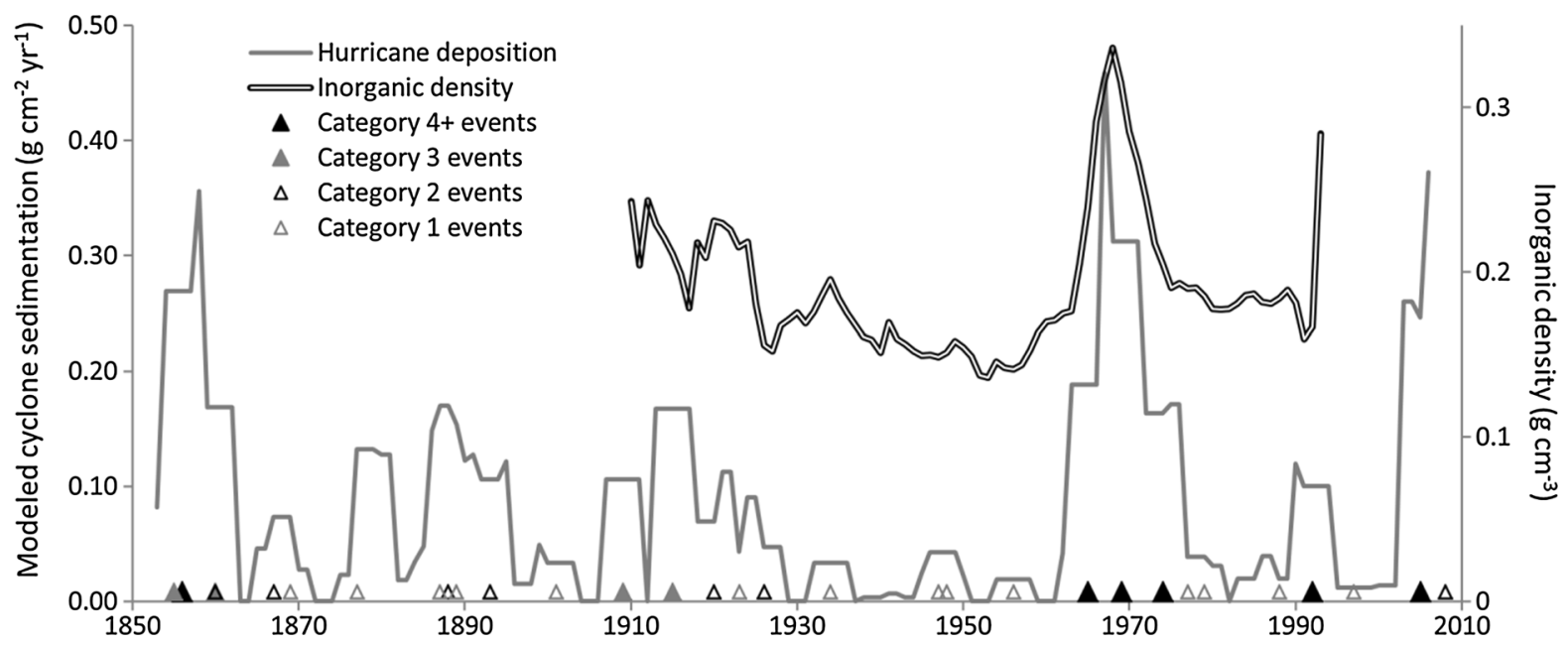

Fig. 7 Temporal distribution of estimated hurricane sedimentation for deltaic plain salt marshes, shown as 5-year averages. Data are compared to the inorganic sediment density of deltaic

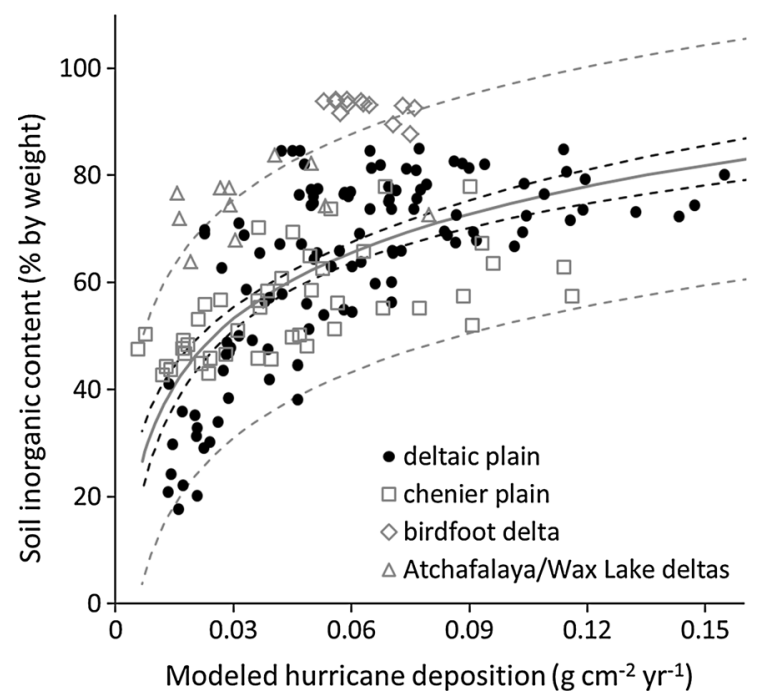

Fig. 8 Comparison of modeled hurricane deposition and soil type for Louisiana coastal marshes. The curve is logarithmically fit to data for deltaic plain and chenier plain marshes. Soil data from the Atchafalaya/Wax Lake deltas and birdfoot delta are clustered above most points from the coastal plains. The outer bands mark the $95 \%$ prediction interval and the inner bands mark the $95 \%$ confidence interval

and reductions in riverine sediment supply to deltaic wetlands (Turner 1997; Tweel and Turner 2012b).

The differing storm strengths in this analysis provide an opportunity to investigate their relationship to sediment deposition. Although the three hurricanes studied made landfalls in different locations, with plain salt marsh soils presented in Turner et al. (2007). Deltaic plain hurricane landfalls are marked by triangles at the bottom (McAdie et al. 2009)

different approach angles and forward speeds, they fall within the range of the most frequent approach angles and forward speeds. In this regard, we would expect the high correlation $\left(R^{2}=0.99\right)$ between sediment deposition and barometric pressure to co-vary with additional storm characteristics. Previously published storm surge models nonetheless suggest that the characteristics of storm intensity have a greater influence than forward speed or approach angle (Irish et al. 2011). Therefore, we have no reason to reject this model based on currently available data. More data are needed to improve these estimates and better understand the relationship between storm characteristics and the spatial distribution of sediment deposition both on wetlands and in shallow inshore waters for large, infrequent hurricanes as well as smaller, more frequent tropical storms or depressions.

\section{Conclusions}

Hurricane storm surge sedimentation events appear to be the dominant source of inorganic sediment for the $80 \%$ of the Louisiana coast that comprises abandoned delta lobes and the chenier plain. This large-scale reworking of deltaic sediments in an offshore to inshore direction is consistent with the distribution of soil types along the coast that generally decrease in mineral content with distance from the Gulf of 
Mexico. Louisiana coastal marshes farther inland (30 km or more) are supplied with less mineral sediment from these events, and consequently maintain elevation by predominantly organic processes, as evidenced by continuous peat deposits that pre-date modern anthropogenic landscape modifications. We expect that future changes in storm frequency or intensity, coupled with both isostatic and eustatic sea level rise, would result in changes to the distribution and magnitude of these sedimentation events.

Acknowledgments AT received the support of a Louisiana Board of Regents Graduate Student Fellowship and Shell Biodiversity in Wetlands Graduate Student Support Fund. Funds to collect the field data came from the NSF Division of Geomorphology and Land-Use Dynamics Awards \#EAR0612501 and \#0900888. We thank C. Milan, M. Kearney, and three anonymous reviewers for helpful comments on the manuscript.

Open Access This article is distributed under the terms of the Creative Commons Attribution License which permits any use, distribution, and reproduction in any medium, provided the original author(s) and the source are credited.

\section{References}

Allison M, Kepple E (2001) Modern sediment supply to the lower delta plain of the Ganges-Brahmaputra River in Bangladesh. Geo-Mar Lett 2:66-74

Barbier EB, Koch EW, Silliman BR, Hacker SD, Wolanski E, Primavera J, Granek EF, Polasky S, Aswani S, Cramer LA, Stoms DM, Kennedy CJ, Bael D, Kappel CV, Perillo GME, Reed DJ (2008) Coastal ecosystem-based management with nonlinear ecological functions and values. Science 319:321-323

Blum MD, Roberts HH (2009) Drowning of the Mississippi Delta due to insufficient sediment supply and global sealevel rise. Nat Geosci 2:488-491

Boldt KV, Lane P, Woodruff JD, Donnelly JP (2010) Calibrating a sedimentary record of overwash from Southeastern New England using modeled historic hurricane surges. Mar Geol 275:127-139

Cahoon DR, Reed DJ, Day JW, Steyer GD, Boumans RM, Lynch JC, McNally D, Latif N (1995) The influence of Hurricane Andrew on sediment distribution in Louisiana coastal marshes. J Coast Res SI 21:280-294

Coastal Protection and Restoration Authority of Louisiana (2012) Louisiana's Comprehensive Master Plan for a Sustainable Coast (Baton Rouge, LA), p 190

Costanza R, Perez-Maqueo O, Martinez ML, Sutton P, Anderson SJ, Mulder K (2008) The value of coastal wetlands for hurricane protection. Ambio 37:241-248

Couvillion BR, Barras JA, Steyer GD, Sleavin W, Fischer M, Beck H, Trahan N, Griffin B, Heckman D (2011) Land Area Change in Coastal Louisiana (1932 to 2010) (US
Geological Survey). Available from http://pubs.usgs.gov/ sim/3164/. Accessed 9 June 2014

Dietrich J, Bunya S, Westerink JJ, Ebersole BA, Smith JM, Atkinson JH, Jensen R, Resio DT, Luettich RA, Dawson C, Cardone VJ, Cox AT, Powell MD, Westerink HJ, Roberts HJ (2010) A high-resolution coupled riverine flow, tide, wind, wind wave, and storm surge model for southern Louisiana and Mississippi. Part II: synoptic description and analysis of Hurricanes Katrina and Rita. Mon Weather Rev 138:378-404

Ebersole B, Westerink J, Bunya S, Dietrich JC, Cialone MA (2010) Development of storm surge which led to flooding in St. Bernard Polder during Hurricane Katrina. Ocean Eng 37:91-103

Freeman AM, Roberts HH (2012) Storm layer deposition on a coastal Louisiana lake bed. J Coast Res 29:31-42

Gedan KB, Kirwan ML, Wolanski E, Barbier EB, Silliman BR (2011) The present and future role of coastal wetland vegetation in protecting shorelines: answering recent challenges to the paradigm. Clim Change 106:7-29

Irish JL, Resio DT, Divoky D (2011) Statistical properties of hurricane surge along a coast. J Geophys Res 116:C10007

Kolb CR, van Lopik JR (1966) Depositional environments of the Mississippi River Deltaic Plain region-Southeastern Louisiana. In: Shirley LS, Ragsdale JA (eds) Deltas in their geologic framework. Houston Geological Society, Houston, pp 17-61

Kosters E, Chmura G, Bailey A (1987) Sedimentary and botanical factors influencing peat accumulation in the Mississippi Delta. J Geol Soc 144:423-434

Mashriqui HS, Kemp GP, van Heerden I, Ropers-Huilman BD, Hyfield E, Yang Y, Streva K, Binselam A (2006) Experimental storm surge simulations for Hurricane Katrina. In: Xu YJ, Singh VP (eds) Coastal environment and water quality. Water Resources Publications, Colorado, pp 481-490

McAdie CJ, Landsea CW, Newmann CJ, David JE, Blake ES (2009) Tropical Cyclones of the North Atlantic Ocean, 1851-2006. (National Hurricane Center, Miami, FL). Available from http://www.nhc.noaa.gov/pdf/TC_Book_ Atl_1851-2006_lowres.pdf. Accessed 9 June 2014

McBride RA, Taylor MJ, Byrnes MR (2007) Coastal morphodynamics and Chenier-Plain evolution in southwestern Louisiana, USA: a geomorphic model. Geomorphology $88: 367-422$

McKee KL, Cherry JA (2009) Hurricane Katrina sediment slowed elevation loss in subsiding brackish marshes of the Mississippi River delta. Wetlands 29:2-15

McKee KL, Cahoon DR, Feller IC (2007) Caribbean mangroves adjust to rising sea level through biotic controls on change in soil elevation. Glob Ecol Biogeogr 16:545-556

Meade RH, Moody JA (2010) Causes for the decline of suspended-sediment discharge in the Mississippi River system, 1940-2007. Hydrol Process 24:35-49

Miner MD, Kulp MA, FitzGerald DM, Flocks JG, Weathers HD (2009) Delta lobe degradation and hurricane impacts governing large-scale coastal behavior, South-central Louisiana, USA. Geo-Mar Lett 29:441-453

Nanayama F, Furukawa R, Shigeno K, Makino A, Soeda Y, Igarashi Y (2007) Nine unusually large tsunami deposits from the past 4000 years at Kiritappu marsh along the southern Kuril Trench. Sediment Geol 200:275-294 
Otvos EG (2011) Hurricane signatures and landforms—-toward improved interpretations and global storm climate chronology. Sediment Geol 239:10-22

Penland S, Boyd R, Suter JR (1988) Transgressive depositional systems of the Mississippi delta plain: a model for barrier shoreline and shelf sand development. J Sediment Res 58:932-949

Piazza SC, Steyer GD, Cretini KF, Sasser CE, Visser JM, Holm Jr. GO, Sharp LA, Evers DE, Meriwether JR (2011) Geomorphic and ecological effects of Hurricanes Katrina and Rita on coastal Louisiana marsh communities. (US Geological Survey). Available from http://pubs.usgs.gov/of/ 2011/1094/OF11-1094.pdf. Accessed 9 June 2014

Rejmanek M, Sasser CE, Peterson GW (1988) Hurricaneinduced sediment deposition in a Gulf coast marsh. Estuar Coast Shelf Sci 27:217-222

Schuerch M, Rapaglia J, Liebetrau V, Vafeidis A, Reise K (2012) Salt marsh accretion and storm tide variation: an example from a Barrier Island in the North Sea. Estuaries Coast 35:486-500

Shepard CC, Crain CM, Beck MW (2011) The protective role of coastal marshes: a systematic review and meta-analysis. PLoS One 6:e27374

Stanley DJ, Warne AG (1994) Worldwide initiation of Holocene marine deltas by deceleration of sea-level rise. Science 265:228-231

Stone GW, Grymes JM III, Dingler JR, Pepper DA (1997) Overview and significance of hurricanes on the Louisiana coast, USA. J Coast Res 13:656-669
Stumpf RP (1983) The process of sedimentation on the surface of a salt marsh. Estuar Coast Shelf Sci 17:495-508

Turner RE (1997) Wetland loss in the northern Gulf of Mexico: multiple working hypotheses. Estuaries Coast 20:1-13

Turner RE, Swenson E, Milan C (2002) Organic and inorganic contributions to vertical accretion in salt marsh sediments. In: Kreeger DA, Weinstein MP (eds) Concepts and controversies in tidal marsh ecology. Springer, Netherlands, pp 583-595

Turner RE, Baustian JJ, Swenson EM, Spicer JS (2006) Wetland sedimentation from hurricanes Katrina and Rita. Science 314:449-452

Turner RE, Swenson EM, Milan CS, Lee JM (2007) Hurricane signals in salt marsh sediments: inorganic sources and soil volume. Limnol Oceanogr 52:1231-1238

Tweel AW, Turner RE (2012a) Landscape-scale analysis of wetland sediment deposition from four tropical cyclone events. PLoS One 7:e50528

Tweel AW, Turner RE (2012b) Watershed land use and river engineering drive wetland formation and loss in the Mississippi River birdfoot delta. Limnol Oceanogr 57:18-28

US Army Corps of Engineers (1972) History of hurricane occurrences along coastal Louisiana. (New Orleans, LA), p 66

Williams HFL (2012) Magnitude of Hurricane Ike storm surge sedimentation: implications for coastal marsh aggradation. Earth Surf Process Landf 37:901-906 